\title{
Pengaruh Penerapan Tata Kelola Perusahaan Terhadap Profitabilitas Perbankan di Indonesia
}

\author{
Renaldi Putra, Yoselin Klen Elia Zakaria, Athalia Ariati Hidayat, Yang Elvi Adelina* \\ Sekolah Bisnis dan Ekonomi - Universitas Prasetiya Mulya \\ BSD City Kavling Edutown I.1 , Jl. BSD Raya Utama, BSD City, Tangerang 15339
}

Keywords:

Corporate Governance, Profitability, ASEAN CG

Scorecard, TARIF

\section{Kata Kunci: \\ Tata Kelola Perusahaan, Profitabilitas, ASEAN $C G$ Scorecard, TARIF}

\section{*Corresponding Author:}

yang.elvi@pmbs.ac.id

\begin{abstract}
This research aims to analyze the impact of corporate governance implementation on profitability of bank in Indonesia. This research measured corporate governance with the score of ASEAN CG Scorecard index and TARIF index, while profitability was measured with ROA, ROE, and NIM ratio. Purposive sampling method was used and managed to gather twenty five samples of listed bank companies from 2011 to 2017. This research compared corporate governance principal of OECD and TARIF within ASEAN CG Scorecard. The result of this research concludes that the implementation of corporate governance does not have significant influence to company's profitability. That is allegedly due to the lack of corporate governance implementation level based on ASEAN CG Scorecard. Banks tend to follow minimum standard of corporate governance by Financial Services Authority of Indonesia that only covered a small part of ASEAN CG Scorecard. The result indicates the need of more detail corporate governance measurement tool that is able to separate mandatory and voluntary disclosure.
\end{abstract}

\section{Sari Pati:}

Penelitian ini bertujuan untuk menganalisis pengaruh penerapan tata kelola perusahaan terhadap profitabilitas perbankan di Indonesia. Tata kelola perusahaan dalam penelitian ini diukur menggunakan indeks ASEAN CG Scorecard dan TARIF sedangkan profitabilitas diukur dengan rasio ROA, ROE, dan NIM. Penelitian menggunakan metode purposive sampling hingga diperoleh sampel penelitian sejumlah dua puluh lima perusahaan perbankan berstatus terbuka pada tahun 2011 sampai tahun 2017. Penelitian dilakukan dengan membandingkan prinsip tata ke lola OECD dan TARIF yang terdapat di dalam ASEAN CG Scorecard. Hasil penelitian menyimpulkan bahwa penerapan tata kelola perusahaan tidak memiliki pengaruh signifikan terhadap profitabilitas perusahaan. Hal tersebut dikarenakan rendahnya tingkat implementasi tata kelola perusahaan berstandar ASEAN CG Scorecard. Perusahaan cenderung mengikuti standar minimum penerapan tata kelola perusahaan yang ditetapkan dan diwajibkan oleh Otoritas Jasa Keuangan yang hanya mencakup sebagian kecil dari ASEAN CG Scorecard. Pengukuran tata kelola perusahaan membutuhkan penilaian yang lebih detail dan dapat memisahkan mekanisme wajib dan sukarela. 


\section{Pendahuluan}

Penerapan tata kelola perusahaan di Indonesia mengalami peningkatan sebesar 44,8 persen dari tahun 2012 sampai 2015 menurut Indonesia Institute of Corporate Directorship. Peningkatan penerapan tata kelola perusahaan di Indonesia dapat terjadi karena peraturan dan supervisi atas keterlaksanaan regulasi tata kelola perusahaan yang meningkat sehingga mendorong perusahaan untuk membangun tata kelola yang lebih baik (Asian Development Bank, 2015). Bentuk kerja keras atas peningkatan implementasi praktik tata kelola perusahaan tersebut merupakan hasil evaluasi dan tindak lanjut dari krisis keuangan 1997 dan 2008 yang salah satu penyebabnya adalah praktik tata kelola perusahaan yang lemah (Otoritas Jasa Keuangan, 2014).

Pada tahun 2011, ASEAN Capital Market Forum menginisiasikan pembentukan sebuah indeks, yaitu ASEAN CG Scorecard yang berfungsi untuk memberi rekomendasi mekanisme sekaligus penilaian terhadap penerapan tata kelola perusahaan di komunitas ASEAN yang akan memasuki era Masyarakat Ekonomi ASEAN di tahun 2015. Pembentukan ASEAN CG Scorecard didasarkan pada lima prinsip utama tata kelola perusahaan menurut OECD yang berbentuk indeks penilaian. Inisiatif ASEAN Capital Market Forum ini bertujuan untuk menetapkan standar tata kelola perusahaan-perusahaan regional ASEAN, meningkatkan visibilitas kepada investor, dan mempersiapkan ASEAN yang didominasi oleh negara berkembang sebagai tujuan investasi yang tepat.

Demi memberi urgensi kepada perusahaan untuk meningkatkan implementasi tata kelola perusahaan di Indonesia, khususnya di sektor perbankan, pemerintah mengeluarkan surat edaran kepada seluruh bank umum di Indonesia perihal pelaksanaan tata kelola perusahaan yang baik oleh Bank Indonesia nomor 8/4/PBI/2006 pada tanggal 30 Januari 2006. Pemerintah terus berupaya memperkuat tata kelola perusahaan di perbankan dengan mengeluarkan peraturan-peraturan seperti Peraturan Otoritas Jasa Keuangan (OJK) Nomor 55/POJK.03/2016 yang mengatur mengenai 
penerapan tata kelola bagi bank umum dan pedoman tata kelola perusahaan perbankan Indonesia oleh Komite Nasional Kebijakan Governance (KNKG).

Perbankan memegang peranan yang sangat dominan pada kondisi keuangan negara berkembang dan merupakan penggerak utama pertumbuhan ekonomi (King \& Levine, 1993; Levine, 1997). Sektor keuangan selain bank di negara berkembang masih belum maksimal, maka sumber dana utama dari perusahaan berasal dari perbankan. Perbankan juga masih menjadi sarana utama penghimpunan dana di negara berkembang (Arun \& Turner, 2004). Selain itu, peningkatan tata kelola perusahaan di perusahaan juga akan meningkatkan nilai perusahaan yang bergerak di sektor keuangan dan mengurangi risiko yang dihadapi perusahaan (Akhigbe \& Martin, 2006). Di sisi lain, tata kelola perusahaan yang buruk dapat menghambat potensi perusahaan, membuat perusahaan tertimpa krisis keuangan, dan menambah peluang terjadinya kecurangan (OECD, 2015). Menurut Shleifer dan Vishny (1997), tata kelola perusahaan memiliki andil yang besar dalam melindungi investor. Tanpa adanya tata kelola perusahaan, investor tidak dapat memastikan bahwa dana yang telah ditanamkan ke perusahaan dapat dikelola dengan baik dan tidak dapat mengontrol kinerja manajer.

Penelitian-penelitian terdahulu menggunakan pengukuran yang sangat beragam dan perbedaan lokasi penelitian menemukan hasil yang berbeda. Owusu dan Weir (2016) melakukan penelitian dengan topik tata kelola perusahaan dan hubungannya terhadap performa perusahaan yang diukur oleh Ghanaian Corporate Governance Index. Penelitian di Turki oleh Ararat, Black, \& Yurtoglu (2017) mengembangkan Turkey Corporate Governance Index untuk dapat menyesuaikan dengan kondisi negara yang diteliti. Secara keseluruhan, mayoritas penelitian yang mengukur tata kelola perusahaan yang terdiri dari beberapa mekanisme dan diukur menggunakan indeks menyimpulkan pengaruh yang positif terhadap profitabilitas (Ararat, Black, \& Yurtoglu, 2017; Owusu \& Weir, 2016). Penelitian di Indonesia menunjukkan bahwa penerapan tata kelola perusahaan memberikan pengaruh terhadap peningkatan profitabilitas dan kinerja perusahaan (Hastuti, 2005; Kaihatu, 2006; Prasinta, 2012; Sukasih \& Susilawati, 2011; Satriadi, Bagaskara, Pranoto, \& Haryono, 2018). 
Walaupun tata kelola perusahaan secara keseluruhan menunjukkan hubungan positif terhadap profitabilitas, apabila dilihat per komponen, hasilnya masih belum konsisten di lokasi penelitian yang berbeda. Contohnya, Owusu dan Weir (2016) dan Zabri, Ahmad, dan Wah (2015) menyimpulkan bahwa banyaknya jumlah anggota dewan komisaris tidak memiliki dampak yang signifikan terhadap profitabilitas perusahaan. Penerapan tata kelola perusahaan di dalam beberapa penelitian justru dapat merugikan perusahaan karena biaya implementasi yang lebih tinggi daripada peningkatan profitabilitas yang terjadi (Beltratti \& Stulz, 2012; Fortin, Goldberg, \& Roth, 2010). Bahkan Erkens, Hung, dan Matos (2012) menyimpulkan bahwa semakin besar independensi dewan komisaris akan berdampak pada penurunan nilai saham perusahaan. Brown dan Caylor (2006) berpendapat bahwa penilaian mekanisme tata kelola perusahaan yang menggunakan sarana berupa indeks yang melingkupi berbagai mekanisme akan memiliki penjelasan yang lebih baik dibanding pengukuran individual mekanisme tata kelola perusahaan terhadap profitabilitas.

Tata kelola perusahaan yang diteliti dalam penelitian ini didefinis ikan melalui lima prinsip utama dari tata kelola perusahaan OECD dan prinsip tata kelola perusahaan yang ditetapkan oleh KNKG yaitu Transparency, Accountability, Responsibility, Independency, Fairness (TARIF). TARIF merupakan sebuah kesatuan prins ip tata kelola perusahaan yang saling melengkapi. TARIF menjadi kerangka yang mendasari terciptanya peraturan-peraturan dan ketetapan pemerintah dalam aspek tata kelola perusahaan di Indonesia. Penelitian ini berupaya memberikan kontribusi analisis pembahasan mengenai implementasi tata kelola perusahaan yang lebih komprehensif dengan menganalisis prinsip tata kelola perusahaan yang dikeluarkan OECD dan prinsip TARIF di dalam ASEAN CG Scorecard sebagai mekanisme tata kelola perusahaan yang berpengaruh terhadap profitabilitas perusahaan. Perbandingan tersebut dapat memberikan perspektif baru tentang dampak dari penerapan mekanisme tata kelola perusahaan berstandard regional ASEAN dan penerapan tata kelola perusahaan dengan kerangka dasar tata kelola perusahaan Indonesia. Hal tersebut dikarenakan mayoritas penelitian mengenai tata kelola perusahaan di Indonesia masih meneliti tata kelola perusahaan per komponen dan tidak menyeluruh sebagai satu kesatuan. Perusahaan perbankan menjadi objek penelitian 
mengingat pentingnya peran perbankan bagi ekonomi negara berkembang (Levine, 1997). Maka dari itu, penelitian ini bertujuan untuk menganalisis pengaruh penerapan tata kelola perusahaan terhadap prof itabilitas perbankan di Indonesia.

Sistematika penyajian penelitian pada bagian kedua berisi konsep dasar, tinjauan literatur, pengembangan hipotesis penelitian dan kerangka penelitian. Bagian ketiga dilanjutkan dengan metode penelitian dan model penelitian yang digunakan. Bagian keempat berisi analis is pembahasan dari hasil olah data berdasarkan model penelitian dan tinjauan literatur. Bagian terakhir membahas ikhtisar dari hasil analisis pembahasan, keterbatasan hasil penelitian berdasarkan hasil pene litian, saran untuk perbaikan penelitian ke depan dan implikasi hasil penelitian

\section{Landasan Teori}

\section{Teori Keagenan}

Konflik keagenan yang timbul karena adanya perbedaan kepentingan di sebuah perusahaan dapat membuat agent tidak menjalankan tugasnya untuk memenuhi kepentingan principal yang salah satunya adalah memaksimalkan shareholders value (Jensen \& Meckling, 1976). Shareholders value dapat diukur me lalui profitabilitas karena nilai pasar saham akan meningkat seiring kenaikan laba dari perusahaan. Di sisi lain, agent memiliki kepentingan berbeda, yaitu untuk memperoleh insentif dan memperoleh jabatan atau posisi. Oleh karena itu, tata kelola perusahaan yang baik diperlukan agar agent tetap bergerak dalam pedoman-pedoman yang dibuat untuk menjalankan kepentingan principal (Rankin, Stanton, McGowan, Ferlauto, Tilling, 2012). Menurut Klapper dan Love (2004), kegunaan utama mekanisme tata kelola perusahaan yang baik dalam perusahaan adalah untuk melindungi investor dari keputusan-keputusan manajer yang menguntungkan diri sendiri. Agency cost dapat diminimalkan apabila agent menjalankan tugasnya dengan dibantu tata kelola perusahaan yang baik dan hal tersebut akan berdampak terhadap profitabilitas (Akbar, Poletti Hughes, El-Faitouri, Zulqifar, \& Shah, 2016).

\section{Pengembangan Hipotesis}


Menurut Chauhan, Lakshmi, dan Dey (2016), praktik tata kelola perusahaan yang baik dapat meningkatkan performa perusahaan baik itu market-based dengan ukuran nilai perusahaan, atau operating-based dengan mengukur profitabilitas. Pernyataan tersebut juga didukung oleh Klapper dan Love (2004) yang menyimpulkan bahwa hak-hak pemegang saham yang dijamin oleh tata kelola perusahaan dapat meningkatkan performa perusahaan dari kedua sisi tersebut. Dalam penelitiannya, Black, Kim, Jang, dan Park (2015) menyimpulkan bahwa tata kelola perusahaan dapat meningkatkan performa perusahaan dengan mengurangi transaksi pihak berelasi yang ternyata dapat berdampak negatif terhadap profitabilitas.

Dalam perbankan, perusahaan dengan tata kelola perusahaan yang buruk cenderung mengambil risiko yang besar dalam pemberian kredit. Hasilnya, non performing loan perusahaan akan meningkat dan tentunya berdampak negatif terhadap performa perusahaan (Zagorchev \& Gao, 2015). Di sisi lain, perusahaan perbankan dengan tata kelola perusahaan yang baik akan mampu meredam dan mengontrol risiko yang diambil sehingga tidak berdampak buruk terhadap shareholders value (Diamond \& Rajan, 2009). Zagorchev dan Gao (2015) juga berpendapat bahwa penerapan tata kelola perusahaan yang baik pada perusahaan perbankan akan membuat manajer mewujudkan alokasi modal yang efisien dan meningkatkan market share yang dapat berdampak terhadap profitabilitas. Peni dan Vähämaa (2012) menyatakan bahwa perusahaan yang bergerak di sektor keuangan dengan struktur tata kelola perusahaan yang baik memperlihatkan profitabilitas yang lebih besar.

Prinsip tata kelola perusahaan tidak dapat dipisahkan dan harus diteliti bersamaan karena keterkaitan antarmekanisme yang erat bisa menjadi pelengkap atau substitusi (Chauhan et al., 2016). Black (2001) melakukan penelitian pertama yang menggunakan indeks tata kelola perusahaan dan pengaruhnya terhadap profitabilitas. Hasilnya, hubungan antara nilai indeks dan profitabilitas sangat kuat dan positif. Penelitian-penelitian berikutnya mengenai tata kelola perusahaan yang menggunakan ukuran indeks mayoritas menunjukkan hasil yang signifikan positif atas pengaruh tata kelola perusahaan terhadap profitabilitas perusahaan (Owusu \& Weir, 2016; Ararat et al., 2016; Chauhan et al., 2016; Cheung, Connelly, Jiang, Limpaphayom 2011; Klapper \& Love, 2004). 
Penelitian-penelitian tersebut memiliki ukuran indeks yang berbeda dan disesuaikan dengan kebijakan tata kelola perusahaan di setiap lokasi penelitian. Penelitian ini menggunakan prinsip tata kelola perusahaan OECD dan TARIF yang terkandung di dalam ASEAN CG Scorecard untuk menilai penerapan tata kelola perusahaan dari perusahaan yang akan dianalisis pengaruhnya kepada profitabilitas bank. Maka dari itu, hipotesis dari penelitian ini adalah:

H1. Penerapan tata kelola perusahaan berpengaruh positif terhadap profitabilitas perbankan di Indonesia.

\section{Kerangka Penelitian}

Berdasarkan telaah literatur dan pengembangan hipotesis, maka kerangka penelitian untuk menganalisis hipotesis yang telah dibentuk terdapat pada gambar 1 .

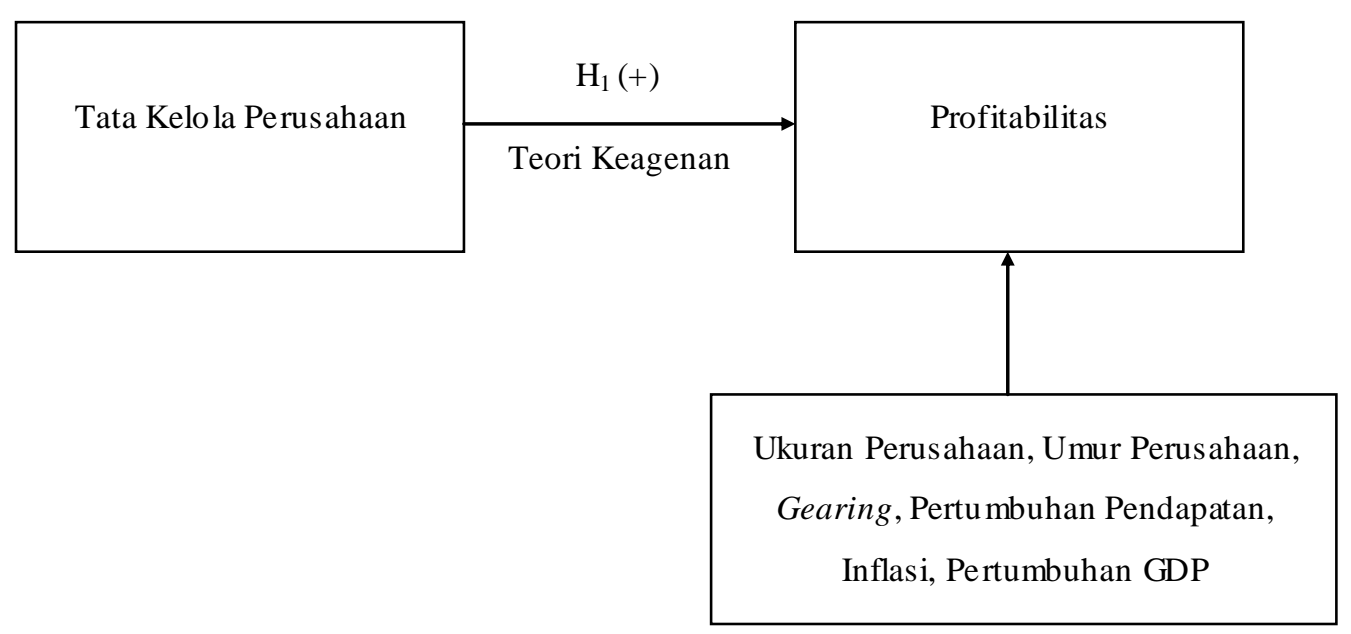

Gambar 1. Ke rangka Penelitian 
Tata kelola perusahaan dan variabel-variabel kontrol ukuran perusahaan, umur perusahaan, gearing, pertumbuhan pendapatan, inflasi, dan pertumbuhan GDP berdampak positif terhadap profitabilitas perbankan di Indonesia yang didukung oleh teori keagenan.

\section{Metode Penelitian}

\section{Penetapan Sampel}

Penelitian ini bertujuan untuk menguji pengaruh tata kelola perusahaan terhadap profitabilitas perusahaan sektor perbankan yang terdaftar di Bursa Efek Indonesia (BEI) pada tahun 2011-2017. Jenis data yang digunakan untuk menarik kesimpulan dalam penelitian ini adalah data sekunder. Data sekunder yang digunakan dalam penelitian ini adalah laporan tahunan perusahaan perbankan tahun 2011-2017 yang dipublikasikan dan diperoleh melalui situs resmi perusahaan atau situs BEI, laporan tata kelola perusahaan perusahaan perbankan tahun 2011-2017 yang diperoleh melalui situs resmi perusahaan, Situs Bank Indonesia dan Badan Pusat Statistik tahun 2011-2017, dan Situs Berita Indonesia tahun 2011-2017.

Tabel 1. Pe rolehan Sampel Penelitian

\begin{tabular}{|c|c|c|c|}
\hline No & Kriteria Penetapan Sampel & Jumlah Perusahaan & Jumlah Observasi \\
\hline 1 & $\begin{array}{l}\text { Perusahaan perbankan terbuka yang terdaftar di } \\
\text { BEI }\end{array}$ & 43 & 301 \\
\hline 2 & $\begin{array}{l}\text { Perusahaan perbankan terbuka yang tidak } \\
\text { terdaftar di BEI dari tahun } 2011 \text { sampai tahun } \\
2017\end{array}$ & (13) & $(91)$ \\
\hline 3 & $\begin{array}{l}\text { Perusahaan perbankan terbuka yang tidak } \\
\text { memiliki ke lengkapan data dari tahun } 2011 \\
\text { sampai tahun } 2017\end{array}$ & (5) & $(35$ \\
\hline Sam & el penelitian yang digunakan & 25 & 175 \\
\hline
\end{tabular}

Variabel dependen dalam penelitian ini adalah profitabilitas perusahaan perbankan yang dilihat menggunakan ROA, ROE, dan NIM. perhitungan rasio akan disesuaikan dengan OJK Sesuai 
dengan Surat Edaran Otoritas Jasa Keuangan Nomor 11/SEOJK.03/2015 mengenai pedoman perhitungan rasio keuangan, perhitungan ROA berasal dari laba sebelum pajak terhadap rata-rata total aset. Menurut Ahmed \& Hamdan (2015), rasio ROA menunjukkan tingkat efisiensi manajemen dalam menghasilkan pendapatan melalui total aset perusahaan. ROE diperoleh dari perhitungan laba setelah pajak terhadap rata-rata ekuitas, rasio ROE telah digunakan sebagai salah satu ukuran profitabilitas di berbagai penelitian terdahulu (Akben-Selcuk, 2016; Owusu dan Weir, 2016; Seuraj dan Watson, 2012). Rasio NIM diperoleh dari pendapatan bunga bersih dibagi dengan rata-rata aset produktif, Seuraj dan Watson (2012) menggunakan NIM sebagai salah satu pengukuran profitabilitas dan kinerja perusahaan perbankan.

Variabel independen tata kelola perusahaan diteliti dengan menggunakan indeks ASEAN CG scorecard dan juga pemetaan ASEAN CG scorecard ke dalam prinsip TARIF. Konsisten dengan penelitian terdahulu (Owusu dan Weir, 2016) penelitian ini menggunakan beberapa variabel kontrol. Pada penelitian ini variabel kontrol yang digunakan yaitu variabel ukuran perusahaan, umur perusahaan, gearing, pertumbuhan perusahaan, inflasi, dan pertumbuhan GDP.

\section{Referensi Silang ASEAN CG Scorecard dan TARIF}

Gambar 2 menunjukan pemetaan prinsip TARIF yang terkandung di dalam ASEAN $C G$ Scorecard. Pemetaan tersebut dilakukan agar diperoleh sebuah indeks tata kelola perusahaan yang menilai penerapan prinsip TARIF dengan tetap berbasis ASEAN CG Scorecard. Dengan adanya dua penilaian, maka penelitian ini dapat memberikan gambaran perbandingan pengaruh dua pengukuran yang berdasarkan pada dua prinsip berbeda terhadap profitabilitas perbankan di Indonesia. Pertanyaan yang terdapat pada ASEAN CG Scorecard berjumlah 184 pertanyaan dan menjadi penilaian pertama. Penilaian kedua juga menggunakan basis ASEAN CG Scorecard, tetapi pertanyaan-pertanyaan di dalamnya kemudian dipetakan menurut prinsip TARIF dan menghasilkan 119 pertanyaan. Prinsip tanggung jawab dewan yang terdapat dalam ASEAN CG Scorecard dipetakan sebanyak 56 pertanyaan ke dalam prinsip accountability dan sembilan pertanyaan ke dalam prinsip independency. Tujuh pertanyaan dalam prinsip responsibility yang terdapat di penilaian TARIF merupakan indeks 
berisi rasio-rasio keuangan yang dibuat berdasarkan peraturan-peraturan perbankan. Hal tersebut didasarkan pada definisi responsibility oleh KNKG (2004) yaitu prinsip kehati-hatian dan kepatuhan perbankan terhadap peraturan-peraturan yang berlaku.

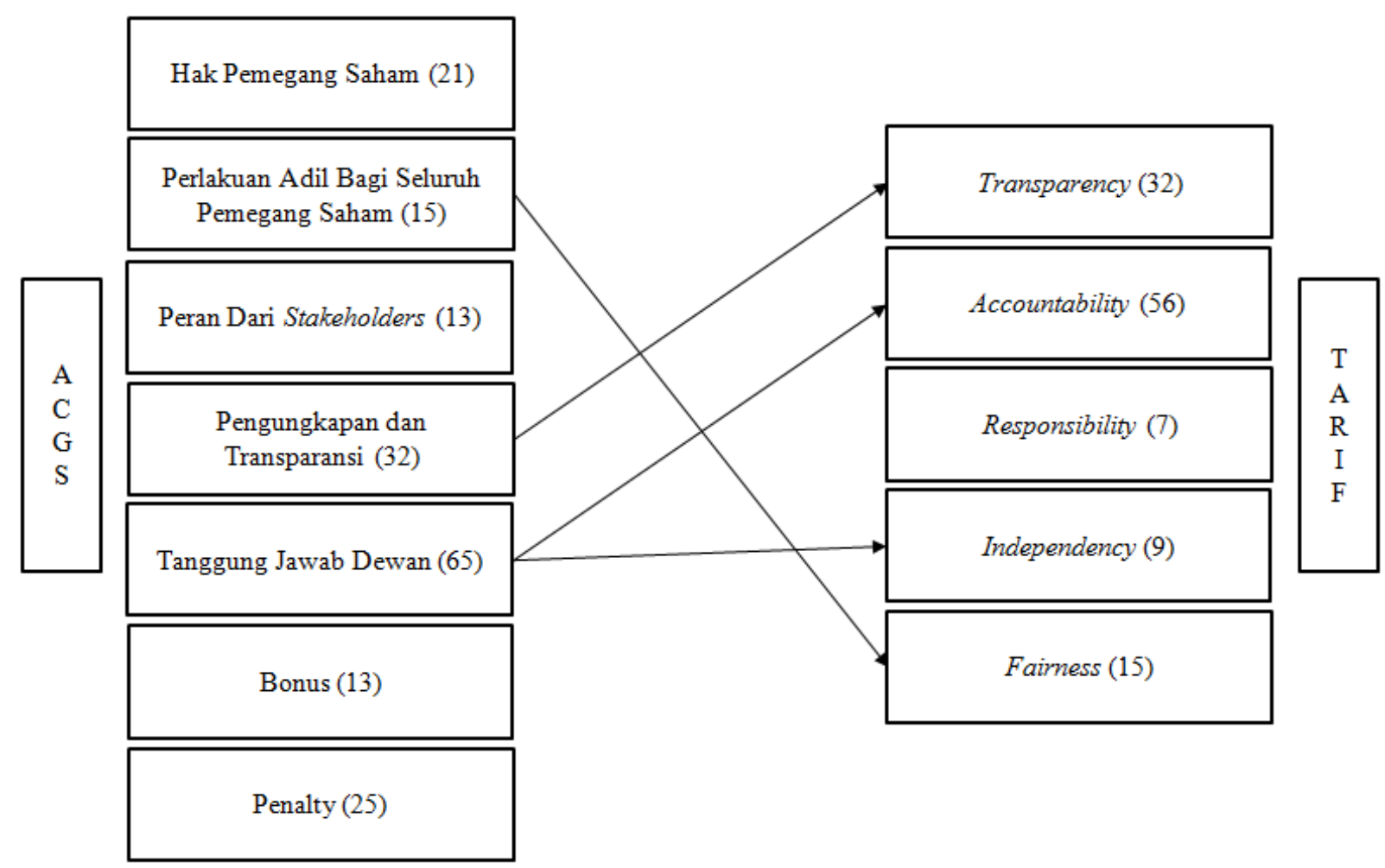

Gambar 2. Keterkaitan Prinsip ASEAN CG Scorecard dan TARIF

\section{Operasionalisasi Variabel}

Tabel 2 memperlihatkan variabel-variabel yang digunakan dalam penelitian ini beserta penjelasannya. Variabel dependen yang digunakan untuk mengukur profitabilitas adalah ROA, ROE, dan NIM. Variabel NIM diikutsertakan karena pendapatan bunga merupakan salah satu sumber pendapatan utama perbankan dan menunjukkan seberapa baik perusahaan mengelola aset produktifnya (Seuraj \& Watson, 2012). Sementara variabel independen yang digunakan untuk mengukur penerapan tata kelola perusahaan memiliki dua pengukuran berbeda, yaitu nilai ASEAN $C G$ Scorecard dan nilai indeks TARIF. Kedua hasil nilai tersebut berbentuk persentase dengan nilai maksimal 113 persen apabila perusahaan menjalankan setiap mekanisme termasuk bonus. 
Mengacu pada penelitian terdahulu yang meneliti pengaruh tata kelola perusahaan terhadap profitabilitas (Akben-Selcuk, 2016; Chauhan et al., 2016; Owusu dan Weir, 2016; Yasser, 2011; Zabri et al., 2015; Seuraj dan Watson, 2012), penelitian ini menggunakan beberapa variabel kontrol yang memengaruhi profitabilitas. Variabel kontrol tersebut adalah ukuran perusahaan (SIZE), umur perusahaan (AGE), rasio gearing (GEAR), pertumbuhan pendapatan (GROWTH), inflasi (INF), dan pertumbuhan GDP (GDPGR).

Tabel 2. Ope rasionalisasi Variabel

\begin{tabular}{|c|c|c|c|}
\hline Variabel & Definisi & Pengukuran & Referensi \\
\hline \multicolumn{4}{|c|}{ Variabel Dependen } \\
\hline $\begin{array}{l}\text { Return on } \\
\text { Assets } \\
\text { (ROA) }\end{array}$ & $\begin{array}{l}\text { Rasio yang mengukur } \\
\text { kemampuan perusahaan } \\
\text { untuk menghasilkan laba dari } \\
\text { aset. }\end{array}$ & $R O A=\frac{\text { Laba sebelum pajak }}{\text { Rata }- \text { rata total aset }}$ & $\begin{array}{l}\text { Surat Edaran OJK No. } \\
\text { 11/SEOJK.03/2015 }\end{array}$ \\
\hline $\begin{array}{l}\text { Return on } \\
\text { Equity } \\
\text { (ROE) }\end{array}$ & $\begin{array}{l}\text { Rasio yang mengukur laba } \\
\text { setelah pajak terhadap rata- } \\
\text { rata modal inti. }\end{array}$ & $R O E=\frac{\text { Laba setelah pajak }}{\text { Rata }- \text { rata ekuitas }}$ & $\begin{array}{l}\text { Surat Edaran OJK No. } \\
\text { 11/SEOJK.03/2015 }\end{array}$ \\
\hline $\begin{array}{l}\text { Net Interest } \\
\text { Margin } \\
\text { (NIM) }\end{array}$ & $\begin{array}{l}\text { Rasio yang mengukur } \\
\text { kemampuan bank dalam } \\
\text { mengelo la aktiva } \\
\text { produktifnya untuk } \\
\text { menghasilkan laba bersih. }\end{array}$ & $N I M=\frac{\text { Pendapatan bunga bersih }}{\text { Rata }- \text { rata aset produktif }}$ & $\begin{array}{l}\text { Surat Edaran OJK No. } \\
\text { 11/SEOJK.03/2015 }\end{array}$ \\
\hline
\end{tabular}

\section{Variabel Inde penden}

\begin{tabular}{llcl}
\hline \multirow{2}{*}{ Tata Kelola } & Penerapan tata kelola & ACGS $=\Sigma$ Skor ACGS & ASEAN Capital Market \\
Perusahaan & perusahaan berdasarkan & TARIF $=\Sigma$ Skor TARIF & Forum \\
& ASEAN CG Scorecard & &
\end{tabular}

Variabel Kontrol

Arosa et al., 2013;

Ukuran

Perusahaan Jumlah aset perusahaan.

(SIZE)
Jermias dan Gani, 2014;

Krivogorsky, 2006;

Mashayekhi dan Bazaz, 2008 
Umur
Perusahaan

(AGE)

Umur perusahaan dari awal terbentuk hingga akhir 2016.

Gearing Penggunaan dana melalui

(GEA R) modal pinjaman.

$$
\begin{gathered}
A G E=\text { Tahun sekarang - } \\
\text { Tahun pendirian }
\end{gathered}
$$

$$
G E A R=\frac{\text { Liabilitas }}{\text { Liabilitas }+ \text { Ekuitas }}
$$

Krivogorsky, 2006;

Mashayekhi dan Bazaz, 2008

Owusu \& Weir, 2016 (GROWTH) perusahaan pertahun.
Pertu mbuhan Pertumbuhan pendapatan

$$
\text { GROWTH } H_{t}=
$$

Pendapatan $_{t}-$ Pendapatan $_{t-1} \quad$ Owusu \& Weir, 2016
Inflasi (INF) Inflasi tahunan Indonesia.

$$
I N F=\text { Inflasi }_{t}
$$

Perry, 1992; Pasiouras

\& Kos midou, 2007

Hassan \& Bashir, 2003;

Pertu mbuhan

GDP

(GDPGR)
Pertu mbuhan GDP di

Indonesia.
$G D P G R_{t}=\frac{G D P_{t}-G D P_{t-1}}{G D P_{t}}$

\section{Metode Analisis Data}

Model 1:

$R O A_{i t}=\propto_{i t}+\beta_{1} A C G S_{i t}+\beta_{2} S I Z E_{i t}+\beta_{3} A G E_{i t}+\beta_{4} G E A R_{i t}+\beta_{5} G R O W T H_{i t}+\beta_{6} B U K U_{i t}+$ $\beta 7 I N F i t+\beta 8 G D P G R i t+\varepsilon i t$

Model 2:

$R O E_{i t}=\propto_{i t}+\beta_{1} A C G S_{i t}+\beta_{2} S I Z E_{i t}+\beta_{3} A G E_{i t}+\beta_{4} G E A R_{i t}+\beta_{5} G R O W T H_{i t}+\beta_{6} B U K U_{i t}+$ $\beta 7 I N F i t+\beta 8 G D P G R i t+\varepsilon i t$

Model 3:

$N I M_{i t}=\propto_{i t}+\beta_{1} A C G S_{i t}+\beta_{2} S I Z E_{i t}+\beta_{3} A G E_{i t}+\beta_{4} G E A R_{i t}+\beta_{5} G R O W T H_{i t}+\beta_{6} B U K U_{i t}+$ $\beta 7 I N F i t+\beta 8 G D P G R i t+\varepsilon i t$

Model 4:

$R O A_{i t}=\propto_{i t}+\beta_{1} T_{A R I F_{i t}}+\beta_{2} S I Z E_{i t}+\beta_{3} A G E_{i t}+\beta_{4} G E A R_{i t}+\beta_{5} G R O W T H_{i t}+\beta_{6} B U K U_{i t}+$ $\beta 7 I N F i t+\beta 8 G D P G R i t+\varepsilon i t$

Model 5:

$R O E_{i t}=\propto_{i t}+\beta_{1} T_{A R I F_{i t}}+\beta_{2} S_{I Z E_{i t}}+\beta_{3} A G E_{i t}+\beta_{4} G E A R_{i t}+\beta_{5} G R O W T H_{i t}+\beta_{6} B U K U_{i t}+$ $\beta 7 I N F i t+\beta 8 G D P G R i t+\varepsilon i t$

Model 6: 
$N I M_{i t}=\propto_{i t}+\beta_{1} T_{A R I F_{i t}}+\beta_{2} \operatorname{SIZE}_{i t}+\beta_{3} A G E_{i t}+\beta_{4} G E A R_{i t}+\beta_{5} G R O W T H_{i t}+\beta_{6} B U K U_{i t}+$ $\beta 7 I N F i t+\beta 8 G D P G R i t+\varepsilon i t$

Untuk memilih penggunaan metode regresi yang tepat, maka penelitian ini melakukan tiga pengujian ketepatan model, yaitu uji Hausman, uji Lagrange Multiplier (LM), dan uji Chow. Uji Hausman dan uji LM menyatakan bahwa penelitian ini paling tepat menggunakan random effect, sedangkan uji Chow menyarankan penggunaan fixed effect. Maka dari itu, penelitian ini menggunakan metode random effect dalam meregresi persamaan dalam enam model tersebut. Penelitian ini juga melakukan pengujian asumsi klasik untuk memenuhi kriteria Best Linear Unbiased Estimator (BLUE) yang disarankan oleh Gujarati (2009) guna memperoleh hasil regresi yang valid. Uji asumsi klasik yang dilakukan adalah uji normalitas, uji multikolinearitas, uji autokorelasi, dan uji heteroskedastisitas.

Setelah melakukan uji asumsi klasik, keenam model memiliki persebaran data yang tidak normal setelah dilakukan uji normalitas Saphiro-Wilk. Akan tetapi, Altman dan Bland (1995) menyatakan bahwa dengan besarnya sampel data yang berada di atas empat puluh observasi, data yang tidak terdistribusi dengan normal tidak akan menyebabkan permasalahan yang signifikan dalam penelitian. Model ketiga dan keenam yang menggunakan variabel dependen NIM mengalami gejala autokorelasi. Untuk itu, dalam melakukan regresi dilakukan treatment untuk menghilangkan permasalahan autokorelasi dengan estimator varian Huber/White.

\section{Analisis dan Pembahasan}

\section{Statistik Deskriptif}

Tabel 3 menunjukkan hasil pengolahan statistik deskriptif dari 25 perusahaan perbankan dengan jumlah 175 observasi pada tiap variabel. Secara keseluruhan nilai rata-rata untuk variabel ROA, ROE, dan NIM adalah 0,017, 0,091, dan 0,052. Variabel AGE yang mengukur umur perusahaan memiliki standar deviasi yang paling tinggi yaitu 26,847. Hal tersebut dikarenakan terdapat beberapa bank yang baru berdiri selama belasan tahun seperti PT Bank Mandiri Tbk dan PT Bank Pembangunan Daerah Banten Tbk, dan bank yang sudah berdiri selama lebih dari seratus tahun 
seperti PT Bank Rakyat Indonesia Tbk dan PT Bank Tabungan Negara Tbk. Namun, lama berdirinya perusahaan tidak selalu menunjukkan pertumbuhan yang positif dapat dilihat dari rata-rata GROWTH perusahaan masih sangat buruk yang menunjukkan posisi negatif 0,213 .

Nilai terendah dari penilaian ASEAN CG Scorecard yaitu 43,673 diperoleh PT Bank China Construction Bank Indonesia dan skor tertinggi diraih oleh PT Bank CIMB Niaga dengan nilai 89,417. Rata-rata hasil penilaian ASEAN CG Scorecard dan penilaian TARIF tidak memiliki perbedaan yang signifikan yaitu dengan skor 67,506 dan 68,749. Sebanyak delapan belas dari 25 perusahaan memiliki nilai indeks TARIF yang lebih tinggi. Hal tersebut dapat terjadi karena perbankan di Indonesia te lah berpedoman pada prins ip TARIF sejak tahun 2004, sedangkan ASEAN CG Scorecard baru dibentuk pada tahun 2011. Perbedaan yang tidak signifikan disebabkan karena penilaian TARIF yang dite liti menggunakan basis ASEAN CG Scorecard.

Tabel 3. Statis tik Desk riptif Variabel Pe nelitian

\begin{tabular}{|c|c|c|c|c|c|c|c|c|}
\hline Variabel & $\mathbf{N}$ & Min & $\operatorname{Max}$ & Mean & Median & $\begin{array}{c}\text { Std. } \\
\text { De viasi }\end{array}$ & Skewness & Kurtosis \\
\hline \multicolumn{9}{|c|}{ Variabel Dependen } \\
\hline ROA & 175 & $-0,475$ & 0,047 & 0,017 & 0,019 & 0,020 & $-1,609$ & 6,321 \\
\hline ROE & 175 & $-0,83$ & 0,304 & 0,105 & 0,122 & 0,151 & $-1,816$ & 6,783 \\
\hline NIM & 175 & 0,019 & 0,113 & 0,055 & 0,052 & 0,022 & 0,902 & 3,772 \\
\hline \multicolumn{9}{|c|}{ Variabel Inde penden } \\
\hline ACGS & 175 & 43,673 & 89,417 & 67,506 & 70,045 & 10,858 & $-0,241$ & 2,097 \\
\hline TARIF & 175 & 46,218 & 86,555 & 68,749 & 70,588 & 9,114 & $-0,437$ & 2,419 \\
\hline \multicolumn{9}{|c|}{ Variabel Kontrol } \\
\hline SIZE & 175 & 3,318 & 7,989 & 4,780 & 4,880 & 0,744 & 0,322 & 0,617 \\
\hline AGE & 175 & 13,00 & 123,000 & 54,046 & 52,000 & 26,847 & 1,078 & 0,836 \\
\hline
\end{tabular}




\begin{tabular}{cccccccccc} 
GEAR & 175 & 0,726 & 0,948 & 0,868 & 0,874 & 0,044 & $-0,805$ & 0,611 \\
GROWTH & 175 & $-1,262$ & 0,482 & 0,034 & 0,135 & 0,389 & $-2,303$ & 7,969 \\
INF & 175 & 0,035 & 0,070 & 0,053 & 0,054 & 0,013 & $-0,064$ & $-1,648$ \\
GDPGR & 175 & 0,049 & 0,062 & 0,054 & 0,051 & 0,005 & 0,556 & $-1,395$ \\
\hline
\end{tabular}

ROA = laba sebelum pajak / rata-rata total aset; ROE = laba setelah pajak / rata-rata ekuitas; NIM = pendapatan bunga bersih / rata-rata aset produktif; ACGS = nilai tata kelola perusahaan berdasarkan ASEAN $C G$ Scorecard; TARIF = nilai tata kelola perusahaan berdasarkan prinsip TARIF; SIZE = ukuran perusahaan; AGE = umur perusahaan; GEAR = rasio solvabilitas perusahaan; GROWTH = pertu mbuhan pendapatan perusahaan; $\mathrm{INF}=$ tingkat inflasi Indonesia; GDPGR = pertu mbuhan GDP Indones ia.

\section{Pembahasan Pengaruh Variabel Independen ke Variabel Dependen}

Tabel 3 menunjukkan hasil regresi enam model dengan metode random effect. Model satu, dua, dan tiga merupakan model yang menggunakan nilai ASEAN CG Scorecard sebagai variabel independen yang memengaruhi profitabilitas (ROA, ROE, dan NIM) sebagai variabel dependen. Hasil dari $p$-value memperlihatkan tidak adanya pengaruh signifikan nilai penerapan tata kelola perusahaan berbasis ASEAN CG Scorecard terhadap profitabilitas. Model empat, lima, dan enam juga menunjukkan hasil yang serupa yaitu pengaruh nilai indeks TARIF yang tidak signifikan terhadap profitabilitas. Apabila dilihat secara keseluruhan, uji hipotes is keenam model menunjukkan pengaruh yang signifikan terhadap variabel dependen yang dapat dilihat dari nilai Prob>chi di bawah 0,05 .

Tabel 3. Hasil Regresi Tata Kelola Perusahaan Terhadap Profitabilitas

\begin{tabular}{|c|c|c|c|c|c|c|}
\hline & \multicolumn{6}{|c|}{ ASEAN CG Scorecard Sebagai Variabel Utama } \\
\hline & \multirow{2}{*}{\multicolumn{2}{|c|}{$\begin{array}{c}\text { Model } 1 \\
\text { ROA }\end{array}$}} & \multirow{2}{*}{\multicolumn{2}{|c|}{$\begin{array}{c}\text { Model } 2 \\
\text { ROE }\end{array}$}} & \multirow{2}{*}{\multicolumn{2}{|c|}{$\begin{array}{c}\text { Model } 3 \\
\text { NIM }\end{array}$}} \\
\hline & & & & & & \\
\hline & Koefisien & $p$-value & Koefisien & p-value & Koefisien & p-value \\
\hline ACGS & 0,000 & 0,679 & 0,000 & 0,986 & 0,000 & 0,833 \\
\hline SIZE & 0,003 & 0,332 & 0,045 & 0,123 & 0,000 & 0,881 \\
\hline AGE & 0,000 & $0,057^{*}$ & 0,001 & $0,033 * *$ & 0,000 & 0,235 \\
\hline GEAR & $-0,065$ & $0,066^{*}$ & 0,021 & 0,915 & 0,009 & 0,899 \\
\hline GROWTH & 0,028 & $0,000 * * *$ & 0,239 & $0,000 * * *$ & 0,012 & $0,000 * * *$ \\
\hline INF & 0,121 & $0,057 *$ & 0,997 & $0,014 * *$ & $-0,022$ & 0,671 \\
\hline
\end{tabular}




\begin{tabular}{|c|c|c|c|c|c|c|}
\hline GDPGR & 0,797 & $0,003 * * *$ & 6,181 & $0,001 * * *$ & 0,343 & 0,119 \\
\hline _cons & $-0,005$ & 0,862 & $-0,567$ & $0,001 * * *$ & 0,026 & 0,728 \\
\hline Prob $>$ chi $^{2}$ & \multicolumn{2}{|c|}{0,000} & \multicolumn{2}{|c|}{0,000} & \multicolumn{2}{|c|}{0,000} \\
\hline $\mathrm{R}^{2}$ & \multicolumn{2}{|c|}{0,606} & \multicolumn{2}{|c|}{0,729} & \multicolumn{2}{|c|}{0,082} \\
\hline
\end{tabular}

TARIF Sebagai Variabel Utama

\begin{tabular}{|c|c|c|c|c|c|c|}
\hline & \multicolumn{2}{|c|}{$\begin{array}{c}\text { Model } 4 \\
\text { ROA }\end{array}$} & \multicolumn{2}{|c|}{$\begin{array}{c}\text { Model } 5 \\
\text { ROE }\end{array}$} & \multicolumn{2}{|c|}{$\begin{array}{c}\text { Model } 6 \\
\text { NIM }\end{array}$} \\
\hline & Koefisien & p-value & Koefisien & $p$-value & Koefisien & $p$-value \\
\hline TARIF & 0,000 & 0,678 & 0,000 & 0,993 & 0,000 & 0,574 \\
\hline SIZE & 0,003 & 0,308 & 0,047 & 0,108 & 0,000 & 0,996 \\
\hline AGE & 0,000 & $0,057^{*}$ & 0,001 & $0,037 * *$ & 0,000 & 0,212 \\
\hline GEA R & $-0,066$ & $0,065^{*}$ & 0,015 & 0,940 & 0,007 & 0,921 \\
\hline GROWTH & 0,028 & $0,000^{* * *}$ & 0,239 & $0,000 * * *$ & 0,012 & $0,019 * *$ \\
\hline INF & 0,117 & $0,046^{* *}$ & 0,992 & $0,010 * * *$ & $-0,039$ & 0,455 \\
\hline GDPGR & 0,785 & $0,001 * * *$ & 6,175 & $0,001 * * *$ & 0,263 & 0,240 \\
\hline _cons & $-0,004$ & 0,886 & $-0,563$ & $0,001 * * *$ & 0,042 & 0,588 \\
\hline Prob $>\mathrm{chi}^{2}$ & \multicolumn{2}{|c|}{0,000} & \multicolumn{2}{|c|}{0,000} & \multicolumn{2}{|c|}{0,000} \\
\hline $\mathrm{R}^{2}$ & \multicolumn{2}{|c|}{0,606} & \multicolumn{2}{|c|}{0,730} & \multicolumn{2}{|c|}{0,064} \\
\hline
\end{tabular}

$\mathrm{ROA}$ = laba sebelum pajak / rata-rata total aset; ROE = laba setelah pajak / rata-rata ekuitas; NIM = pendapatan bunga bersih / rata-rata aset produktif; ACGS = nilai tata kelola perusahaan berdasarkan ASEAN CG Scorecard TARIF = nilai tata kelola perusahaan berdasarkan prinsip TARIF; SIZE = ukuran perusahaan; AGE = umu r perusahaan; GEAR = rasio solvabilitas perusahaan; GROWTH = pertu mbuhan pendapatan perusahaan; $\mathrm{INF}=$ tingkat inflasi Indonesia; GDPGR = pertumbuhan GDP Indonesia, _cons $=$ konstanta, Prob $>\mathrm{chi}^{2}=u j i$ simultan, $\mathrm{R}^{2}=$ koefisien determinasi.

Hasil tersebut tidak konsisten dengan penelitian-penelitian terdahulu yang menyimpulkan adanya pengaruh signifikan positif penerapan tata kelola perusahaan yang diukur menggunakan indeks terhadap profitabilitas (Owusu \& Weir, 2016; Ararat et al., 2016; Chauhan et al., 2016; Cheung et al., 2011; Klapper \& Love, 2004). Perbedaan hasil yang diperoleh dapat disebabkan karena penggunaan indeks berbeda-beda yang menyesuaikan dengan kebijakan penerapan tata kelola perusahaan di masing-masing negara. Contohnya, Owusu dan Weir (2016) mengukur tata kelola perusahaan menggunakan Ghanaian CG Index untuk penelitian di Ghana dan Ararat et al. (2016) menggunakan Turkey CG Index untuk penelitian di Turki. Indeks yang berbeda tentu saja memiliki kriteria penilaian yang berbeda dan prinsip yang berbeda. Dalam penelitian ini, penerapan tata kelola 
perusahaan yang diukur dengan ASEAN CG Scorecard terbukti tidak memiliki pengaruh signifikan terhadap profitabilitas perusahaan yang bergerak di bidang perbankan di Indonesia baik dengan penilaian ASEAN CG Scorecard dan TARIF.

Perbedaan besaran $\mathrm{R}^{2}$ terlihat pada semua model. Model yang pengukuran profitabilitasnya menggunakan ROA dan ROE cenderung memiliki $\mathrm{R}^{2}$ yang lebih tinggi yakni diatas $60 \%$, sedangkan model yang pengukuran profitabilitasnya menggunakan NIM cenderung memiliki $\mathrm{R}^{2}$ yang rendah, yakni hanya dibawah 10\%. Proksi ROA dan ROE menunjukkan kemampuan perusahaan untuk menghasilkan laba dari aset dan ekuitasnya, proksi NIM lebih cenderung mencerminkan eksposur pendapatan bank yang bersifat interest bearing (pendapatan bunga), berasal dari aktiva produktif kredit yang disalurkan Bank. Walaupun pada umumnya Bank memiliki ekposur pendapatan tidak hanya berasal dari pendapatan bunga saja namun juga fee based income yang bersifat non interest bearing, namun pada proksi dari variabel penelitian tidak dapat dieksplorasi lebih lanjut karena adanya keterbatasan cara ukur proksi itu sendiri. Model dengan $\mathrm{R}^{2}$ yang lebih tinggi dapat dikatakan lebih akurat karena memiliki explanatory power yang lebih tinggi. Namun temuan ini tidak memungkinkan untuk menetapkan model mana yang lebih baik. Hal ini karena masing-masing model mempunyai ukuran profitabilitas yang berbeda.

ASEAN CG Scorecard dibentuk dan dipublikasikan pada tahun 2011 yang menjadi awal periode dari penelitian ini. Tujuan utama dari ASEAN CG Scorecard adalah menetapkan standar tata kelola perusahaan guna menarik investor dalam rangka menghadapi MEA pada akhir tahun 2015. Walaupun demikian, penerapan ASEAN CG Scorecard bukan merupakan kewajiban bagi perusahaan-perusahaan di Indonesia. Di sisi lain, OJK juga mengeluarkan Surat Edaran OJK Nomor 32/SEOJK.04/2015 yang merupakan penilaian berbentuk indeks. Surat edaran tersebut menjadi pilihan utama mayoritas perbankan untuk mengungkapkan penilaian tata kelola perusahaan pada laporan tahunan perusahaan. Peraturan-peraturan tersebut tentu saja bersifat mengikat dan memiliki konsekuensi apabila tidak ditaati. Belum adanya kebijakan atau peraturan yang bersifat mengikat 
menyebabkan penerapan ASEAN CG Scorecard relatif rendah, termasuk dengan penilaian TARIF yang juga didasarkan oleh mekanis me ASEAN CG Scorecard.

Tabel 4 Analisis Konten ASEAN CG Scorecard dan TARIF dengan Surat Edaran OJK

\begin{tabular}{|c|c|c|c|c|c|c|c|}
\hline \multirow{2}{*}{ No. } & \multirow{2}{*}{$\begin{array}{l}\text { ASEAN } C G \\
\text { Scorecard }\end{array}$} & \multicolumn{2}{|c|}{$\begin{array}{l}\text { Surat Edaran OJK No. } \\
\text { 32.SEOJK.04/2015 }\end{array}$} & \multirow{2}{*}{ No. } & \multirow{2}{*}{ TARIF } & \multicolumn{2}{|c|}{$\begin{array}{c}\text { Surat Edaran OJK No. } \\
\text { 32.SEOJK.04/2015 }\end{array}$} \\
\hline & & $\begin{array}{c}\text { Jumlah } \\
\text { Pertanyaan }\end{array}$ & Persentase & & & $\begin{array}{c}\text { Jumlah } \\
\text { Pertanyaan }\end{array}$ & Persentase \\
\hline 1 & $\begin{array}{l}\text { Hak Pemegang } \\
\text { Saham }\end{array}$ & 6 & $3,3 \%$ & 1 & Transparency & 6 & $5 \%$ \\
\hline 2 & $\begin{array}{l}\text { Perlakuan Adil Bagi } \\
\text { Seluruh Pemegang } \\
\text { Saham }\end{array}$ & 2 & $1,1 \%$ & 2 & Accountability & 6 & $5 \%$ \\
\hline 3 & $\begin{array}{l}\text { Peran dari } \\
\text { Stakeholders }\end{array}$ & 7 & $3,8 \%$ & 3 & Responsibility & 0 & $0 \%$ \\
\hline 4 & $\begin{array}{l}\text { Pengungkapan dan } \\
\text { Transparansi }\end{array}$ & 6 & $3,3 \%$ & 4 & Independency & 0 & $0 \%$ \\
\hline 5 & $\begin{array}{l}\text { Tanggung Jawab } \\
\text { Dewan }\end{array}$ & 8 & $4,3 \%$ & 5 & Fairness & 2 & $1,7 \%$ \\
\hline & Total & 29 & $15,8 \%$ & & Total & 14 & $11,8 \%$ \\
\hline
\end{tabular}

Setelah melakukan analisis konten yang terdapat pada tabel 4, ternyata surat edaran OJK yang menjadi indikator penilaian utama bagi perusahaan-perusahaan perbankan hanya mencakup sebesar 15,8 persen dari 184 total mekanisme yang ada di ASEAN CG Scorecard dan 11,8 persen dari penilaian TARIF. Beberapa rekomendasi Surat Edaran OJK yang mencakup mekanisme ASEAN CG Scorecard antara lain teknik prosedur pengumpulan suara, dan kehadiran anggota direksi dan komisaris pada RUPS. Namun, terdapat lebih dari 80 persen mekanisme dalam ASEAN CG Scorecard dan penilaian TARIF yang belum tercakup dalam Surat Edaran OJK seperti kualitas laporan tahunan, laporan audit dan auditor eksternal, pengungkapan transaksi pihak berelasi, hingga orientasi untuk direksi dan komisaris baru. Hal tersebut dapat berdampak terhadap minimnya penerapan mekanisme dalam ASEAN CG Scorecard dan penilaian TARIF akibat penggunaan surat edaran OJK sebagai patokan penilaian penerapan tata kelola perusahaan.

Tabel 5 mendeskripsikan distribusi variabel independen dengan variabel dependen yang dilakukan melalui pembagian kuartil. Pada nilai ASEAN CG Scorecard yang telah diurutkan dari 
nilai terendah hingga nilai tertinggi tidak ditemukan peningkatan yang sejalan dengan variabel dependen. Dapat dilihat bahwa nilai ASEAN CG Scorecard tidak memiliki hubungan yang konsisten terhadap besarnya ROA dan ROE. Terdapat penurunan ROE pada kuartil 4. Nilai TARIF memiliki hubungan yang lebih sejalan dengan ROA dan ROE. Kedua penilaian ASEAN CG Scorecard dan TARIF memiliki hubungan yang sejalan terhadap NIM walaupun tidak signifikan secara statistik. PT Bank Central Asia Tbk, memiliki rata-rata ASEAN CG Scorecard dan nilai TARIF yang berada diatas rata-rata sampel yaitu 82,899 dan 80,672 dengan nilai ROA, ROE, dan NIM yang berada di atas industri yaitu 0,038,0,231, dan 0,080. Di s is i lain, terdapat perusahaan dengan profitabilitas yang kurang baik walaupun memiliki nilai ASEAN CG Scorecard dan nilai TARIF yang berada di atas rata-rata sampel. Contohnya, PT Bank Permata Tbk memperoleh nilai ASEAN CG Scorecard di atas rata-rata yaitu 79,272 dan nilai TARIF 76,471. Akan tetapi, profitabilitas PT Bank Permata Tbk yang dilihat dari rasio ROA, ROE, dan NIM berada pada posisi negatif 0,049 , negatif 0,383 , dan 0,039 sehingga profitabilitas PT Bank Permata Tbk dapat dikatakan rendah. Rendahnya profitabilitas Bank Permata Tbk dikarenakan peningkatan non performing loan gross sebesar 222 persen dibanding tahun lalu, sehingga mengakibatkan perusahaan mengalami kerugian bersih hingga 6,48 triliun rupiah.

Tabel 5. Deskriptif Kuartil Variabel Inde penden

\begin{tabular}{|c|c|c|c|c|c|c|c|c|c|c|}
\hline \multirow{2}{*}{ Kuartil } & \multirow{2}{*}{$\begin{array}{c}\text { Jumlah } \\
\text { Data }\end{array}$} & \multirow{2}{*}{$\begin{array}{c}\begin{array}{c}\text { Variabel } \\
\text { Independen }\end{array} \\
\text { ACGS }\end{array}$} & \multicolumn{3}{|c|}{ Variabel Dependen } & \multirow{2}{*}{$\begin{array}{c}\text { Jumlah } \\
\text { Data }\end{array}$} & \multirow{2}{*}{$\begin{array}{c}\begin{array}{c}\text { Variabel } \\
\text { Independen }\end{array} \\
\text { TARIF }\end{array}$} & \multicolumn{3}{|c|}{ Variabel Dependen } \\
\hline & & & ROA & ROE & NIM & & & ROA & ROE & NIM \\
\hline 1 & 26 & 50,381 & 0,019 & 0,059 & 0,049 & 17 & 51,755 & 0,025 & 0,134 & 0,051 \\
\hline 2 & 48 & 59,900 & 0,011 & 0,045 & 0,051 & 49 & 61,156 & 0,008 & 0,001 & 0,051 \\
\hline 3 & 65 & 72,284 & 0,019 & 0,131 & 0,056 & 76 & 72,534 & 0,018 & 0,124 & 0,055 \\
\hline 4 & 36 & 81,393 & 0,019 & 0,103 & 0,063 & 33 & 80,061 & 0,023 & 0,125 & 0,063 \\
\hline
\end{tabular}

$\mathrm{ROA}$ = laba sebelum pajak / rata-rata total aset; ROE = laba setelah pajak / rata-rata ekuitas; NIM = pendapatan bunga bersih / rata-rata aset produktif; ACGS = nilai tata kelola perusahaan berdasarkan ASEAN CG Scorecard TARIF = nilai tata kelola perusahaan berdasarkan prinsip TARIF

Prinsip tata kelola perusahaan di dalam ASEAN CG Scorecard dengan bobot penilaian tertinggi, yaitu empat puluh persen, adalah tanggung jawab dewan. Prinsip ini bersangkutan dengan bagaimana perusahaan dijalankan melalui orang-orang yang mengawasi dan memimpin perusahaan 
yaitu dewan komisaris dan dewan direksi. Sebagian besar prinsip ini berupaya mengukur independensi dan kompetensi dewan dan komite-komite pendukungnya. Selain itu, prinsip ini juga merekomendasikan adanya manajemen risiko di perusahaan. Akan tetapi, ASEAN CG Scorecard tidak bisa mengukur kualitas dari manajemen risiko yang diterapkan perusahaan ataupun besarnya kompetensi dewan dan komite-komite pendukungnya. Selain itu, dengan bobot penilaian dan kepentingan yang besar, prinsip ini tidak menjadi prinsip dengan persentase penerapan yang paling tinggi apabila dilihat pada Tabel 6 .

Nilai prinsip perlakuan adil bagi seluruh pemegang saham pada ASEAN CG Scorecard dan nilai prinsip fairness pada penilaian TARIF memiliki nilai yang paling rendah setiap tahunnya. Hal ini dapat membuktikan adanya masalah keagenan yang disebabkan perbedaan kepentingan antara pemegang saham mayoritas dan minoritas. Dengan adanya masalah keagenan tersebut, justru tidak dapat terlihat adanya upaya perusahaan untuk menjalankan rekomendasi mekanisme yang berupaya mengatasi masalah tersebut. Upaya mengatasi perbedaan kepentingan antara pemegang saham sebagai principal dan manajemen sebagai agent juga tidak dapat tercermin dalam penelitian ini karena tidak adanya peraturan yang mewajibkan perusahaan di Indonesia untuk menerapkan tata kelola perusahaan berdasarkan ASEAN CG Scorecard sehingga nilai dari implementasi tata kelola perusahaan cenderung rendah. Selain itu, pertanyaan yang terdapat dalam mekanisme ASEAN $C G$ Scorecard yang tidak dapat mengukur kualitas dari implementasi tata kelola perusahaan menyebabkan tidak ada jaminan bahwa selain diungkapkan, rekomendasi mekanisme-mekanisme tersebut benar-benar dijalankan dengan baik oleh perusahaan.

Tabel 6. Persentase Penerapan ASEAN CG Scorecard dan TARIF

\begin{tabular}{|c|c|c|c|c|c|c|c|c|}
\hline & 2011 & 2012 & 2013 & 2014 & 2015 & 2016 & 2017 & Maks \\
\hline \multicolumn{9}{|c|}{ ASEAN CG Scorecard } \\
\hline Hak Pemegang Saham & $34 \%$ & $35 \%$ & $39 \%$ & $42 \%$ & $49 \%$ & $55 \%$ & $59 \%$ & $100 \%$ \\
\hline $\begin{array}{l}\text { Perlakuan Adil Bagi Seluruh } \\
\text { Pemegang Saham }\end{array}$ & $39 \%$ & $40 \%$ & $42 \%$ & $42 \%$ & $46 \%$ & $52 \%$ & $56 \%$ & $100 \%$ \\
\hline Peran dari Stakeholders & $59 \%$ & $65 \%$ & $70 \%$ & $74 \%$ & $78 \%$ & $85 \%$ & $89 \%$ & $100 \%$ \\
\hline $\begin{array}{l}\text { Pengungkapan dan } \\
\text { Transparansi }\end{array}$ & $68 \%$ & $69 \%$ & $71 \%$ & $73 \%$ & $76 \%$ & $79 \%$ & $80 \%$ & $100 \%$ \\
\hline
\end{tabular}




\begin{tabular}{|c|c|c|c|c|c|c|c|c|}
\hline Tanggung Jawab Dewan & $64 \%$ & $66 \%$ & $68 \%$ & $70 \%$ & $71 \%$ & $73 \%$ & $76 \%$ & $100 \%$ \\
\hline \multicolumn{9}{|c|}{ TARIF } \\
\hline Transparency & $68 \%$ & $69 \%$ & $71 \%$ & $73 \%$ & $76 \%$ & $79 \%$ & $80 \%$ & $100 \%$ \\
\hline Accountability & $65 \%$ & $67 \%$ & $68 \%$ & $71 \%$ & $72 \%$ & $74 \%$ & $77 \%$ & $100 \%$ \\
\hline Responsibility & $85 \%$ & $87 \%$ & $89 \%$ & $86 \%$ & $89 \%$ & $87 \%$ & $87 \%$ & $100 \%$ \\
\hline Independency & $64 \%$ & $63 \%$ & $64 \%$ & $65 \%$ & $65 \%$ & $69 \%$ & $68 \%$ & $100 \%$ \\
\hline Fairness & $39 \%$ & $40 \%$ & $42 \%$ & $42 \%$ & $46 \%$ & $52 \%$ & $56 \%$ & $100 \%$ \\
\hline
\end{tabular}

\section{Pembahasan Pengaruh Variabel Kontrol ke Variabel Dependen}

Hasil regresi menunjukan bahwa mayoritas dari variabel kontrol memiliki pengaruh signifikan terhadap ROA dan ROE tetapi tidak terhadap NIM. Hal ini dikarenakan pendapatan bunga bersih merupakan komponen utama dari NIM yang diperoleh dari hasil spread yaitu selisih bunga pinjaman dan bunga simpanan yang merupakan kebijakan dari perusahaan perbankan. Di sisi lain, pendapatan perusahaan memiliki dampak yang signifikan positif terhadap NIM karena pendapatan bunga merupakan sumber utama pendapatan dari perusahaan perbankan. Selain itu, umur perusahaan, rasio gearing, pertumbuhan pendapatan, inflasi, dan pertumbuhan GDP memiliki pengaruh terhadap profitabilitas yang konsisten dengan penelitian-penelitian terdahulu (Akben-Selcuk, 2016; Chauhan et al., 2016; Owusu dan Weir, 2016; Yasser, 2011; Zabri et al., 2015; Seuraj dan Watson, 2012).

Tabel 7. Persebaran Kuartil Variable SIZE

\begin{tabular}{cccccc}
\hline Kuartil & \multirow{2}{*}{ Jumlah Data } & Variabel & \multicolumn{3}{c}{ Variabel Dependen } \\
\cline { 3 - 6 } & & SIZE & ROA & ROE & NIM \\
\hline 1 & 36 & 3.769 & 0.005 & -0.005 & 0.057 \\
2 & 35 & 4.278 & 0.010 & -0.025 & 0.034 \\
3 & 73 & 5.065 & 0.018 & 0.136 & 0.060 \\
4 & 31 & 5.753 & 0.034 & 0.227 & 0.065 \\
\hline
\end{tabular}

Hanya variabel ukuran perusahaan yang tidak menunjukkan pengaruh signifikan terhadap profitabilitas di semua model. Tabel 7 menunjukkan persebaran data variabel ukuran perusahaan (SIZE). Pada tabel 7 dapat dilihat bahwa pada kuartil dua, justru perusahaan dengan ukuran yang lebih besar mengalami kerugian yang lebih besar dibanding perusahaan pada kuartil satu jika dilihat dari proksi ROE. Hal tersebut dapat membantu menjelaskan tidak signifikannya pengaruh ukuran perusahaan dan profitabilitas. 


\section{Kesimpulan, Implikasi, dan Keterbatasan}

Penelitian ini bertujuan menganalisis pengaruh penerapan tata kelola perusahaan terhadap profitabilitas perbankan di Indonesia. Penelitian dilakukan terhadap 25 perusahaan perbankan yang berstatus terbuka dari tahun 2011 sampai tahun 2017. Tata kelola perusahaan diukur dengan menggunakan ASEAN CG Scorecard sebagai standar tata kelola perusahaan regional ASEAN dan penilaian TARIF sebagai kerangka dasar tata kelola perusahaan di Indonesia yang kemudian dipetakan ke dalam ASEAN CG Scorecard. Profitabilitas perbankan dihitung melalui rasio ROA, ROE, dan NIM. Penelitian ini dilakukan dengan model multi regresi dengan pendekatan random effect dan memperoleh hasil bahwa penerapan tata kelola perusahaan tidak berpengaruh secara signifikan terhadap profitabilitas perbankan di Indonesia.

Penerapan tata kelola perusahaan berdasarkan ASEAN CG Scorecard tidak berpengaruh signifikan terhadap profitabilitas karena sifatnya yang sukarela dan tidak adanya konsekuensi apabila terjadi ketidakpatuhan. Penilaian TARIF menunjukkan hasil yang lebih sejalan dalam analisis deskriptif kuartil walaupun tidak signifikan secara statistik. Hal tersebut dikarenakan sebagian besar perusahaan perbankan hanya mematuhi batas minimal penerapan tata kelola perusahaan yang diatur di dalam Surat Edaran OJK Nomor 32/SEOJK.04/2015. Surat edaran tersebut memiliki bentuk penilaian berupa indeks yang ternyata hanya mencakup sebesar 15,8 persen dari aspek penilaian ASEAN CG Scorecard dan 11,8 persen dari aspek penilaian TARIF, dikarenakan ASEAN CG Scorecard memiliki rekomendasi mekanisme yang lebih kompleks dan detail.

Belum adanya peraturan pemerintah untuk meningkatkan standar penerapan tata kelola perusahaan mengikuti standar regional ASEAN dan tidak adanya alat penilaian penerapan tata kelola perusahaan yang komprehensif dapat menjadi alasan mengapa implementasi mekanisme tata kelola perusahaan ASEAN CG Scorecard masih cenderung rendah dan belum menyeluruh bagi seluruh perusahaan perbankan di Indonesia. Karena penerapannya yang rendah, tata kelola perusahaan belum bisa menyelesaikan masalah keagenan dan tidak bisa berdampak signifikan dan positif terhadap perusahaan. Kondisi internal perusahaan juga menjadi salah satu penyebab tingginya penerapan tata 
kelola perusahaan berdasarkan ASEAN CG Scorecard tidak selalu berdampak terhadap tingginya profitabilitas perusahaan. Terdapat perusahaan yang memiliki nilai penerapan tata kelola perusahaan yang tinggi dengan profitabilitas rendah dan profitabilitas tinggi.

Penelitian ini memberikan beberapa implikasi kepada berbagai pihak. Bagi pihak akademik, penelitian dapat menjadi referensi bagi penelitian-penelitian selanjutnya dan menambah penelitian tentang penerapan tata kelola perusahaan di Indonesia dengan standar regional. Untuk investor, penelitian ini dapat menambah pengetahuan bahwa penerapan tata kelola perusahaan yang rendah tidak memiliki dampak signifikan terhadap profitabilitas. Selain itu, investor dapat menilai bahwa profitabilitas yang rendah dapat diimbangi dengan nilai penerapan tata kelola perusahaan yang baik dan sebaliknya nilai penerapan tata kelola perusahaan yang baik tidak menjamin profitabilitas yang tinggi. Bagi perusahaan, penelitian ini dapat menjadi salah satu konsiderasi untuk mengimplementasikan mekanisme tata kelola perusahaan yang melebihi standar minimum pemerintah dan berdampak positif terhadap peningkatan profitabilitas. Bagi pemerintah atau regulator, perlu mempertimbangkan pengeluaran peraturan atau kebijakan yang mewajibkan perusahaan perbankan untuk meningkatkan standar tata kelola perusahaan menjadi setara dengan standar regional ASEAN serta membantu meningkatkan performa perusahaan perbankan dan juga mengeluarkan sebuah perangkat penilaian tata kelola perusahaan yang dapat mengukur mekanisme yang bersifat wajib dan mekanisme yang bersifat sukarela secara terpisah.

Penelitian ini tidak luput dari keterbatasan, misalnya dalam pengisian indeks ASEAN $C G$ Scorecard, terdapat kesulitan untuk mengukur tingkat pelaksanaan dari mekanisme yang direkomendasikan. Beberapa pertanyaan hanya memperhitungkan ada atau tidaknya kebijakan terkait dan hanya berpedoman kepada laporan tahunan dan situs perusahaan. Dalam melakukan penilaian ASEAN CG Scorecard, diperlukan sumber berupa berita mengenai perusahaan untuk menjawab pertanyaan bonus dan penalti. Terdapat kesulitan untuk menyortir dan memperoleh seluruh sumber berita mengenai perusahaan terutama dari media cetak dikarenakan penelitian dilakukan dari tahun 
2011 hingga tahun 2017. Penelitian selanjutnya dapat menuangkan prinsip TARIF tersebut ke dalam indeks yang terdiri dari seluruh peraturan-peraturan tata kelola perusahaan terbuka di Indonesia sehingga diperoleh pertanyaan-pertanyaan atau mekanisme tata kelola perusahaan yang bersifat wajib.

Selain itu, penelitian selanjutnya dapat menggunakan pengukuran indeks tata kelola perusahaan yang berbeda atau membuat indeks yang bisa mengukur kualitas dan tingkat pelaksanaan mekanisme tata kelola perusahaan agar dapat mengukur tingkat penerapan tata kelola perusahaan.

\section{Daftar Pustaka}

Ahmed, E., \& Hamdan, A. (2015). The impact of corporate governance on firm performance: evidence from Bahrain Bourse. International Management Review, 11(2), 21.

Akbar, S., Poletti-Hughes, J., El-Faitouri, R., \& Shah, S. Z. A. (2016). More on the relationship between corporate governance and firm performance in the UK: Evidence from the application of generalized method of moments estimation. Research in International Business and Finance, 38, 417-429.

Akben-Selcuk, E. (2016). Does Firm Age Affect Profitability? Evidence from Turkey.International Journal of Economic Sciences, 5(3), 1-9.

Akhigbe, A., \& Martin, A. D. (2006). Valuation impact of Sarbanes-Oxley: Evidence from disclosure and governance within the financial services industry. Journal of Banking \& Finance, 30(3), 9891006.

Altman, D. G., \& Bland, J. M. (1995). Statistics notes: the normal distribution. Bmj, 310(6975), 298.

Ararat, M., B lack, B. S., \& Yurtoglu, B. B. (2017). The effect of corporate governance on firm value and profitability: Time-series evidence from Turkey. Emerging Markets Review, 30, 113-132.

Arosa, B., Iturralde, T., \& Maseda, A. (2013). The board structure and firm performance in SMEs: Evidence from Spain. Investigaciones Europeas de Dirección y Economía de La Empresa, 19(3), 127-135.

Arun, T. G., \& Turner, J. D. (2004). Corporate Governance of Banks in Developing Economies: concepts and issues. Corporate Governance: An International Review, 12(3), 371-377.

Asian Development Bank. (2015). ASEAN Corporate Governnace Scorecard Country Reports and Assessments 2015. Manila: Asian Development Bank. asean-cgscorecard-2015.pdf

Bank Indonesia. (2006). Peraturan Bank Indonesia No 8/4/PBI/2006, tanggal 30 Januari 2006, Perihal Pelaksanaan Good Corporate Governance bagi Bank Umum.Jakarta. Indonesia.

Beltratti, A., \& Stulz, R. M. (2012). The credit crisis around the globe: Why did some banks perform better? Journal of Financial Economics, 105(1), 1-17.

Black, B. (2001). The corporate governance behavior and market value of Russian firms. Emerging Markets Review, 2(2), 89-108.

Black, B. S., Kim, W., Jang, H., \& Park, K.-S. (2015). How corporate governance affect firm value? Evidence on a self-dealing channel from a natural experiment in Korea. Journal of Banking \& Finance, 51, 131- 150.

Brown, L. D., \& Caylor, M. L. (2006). Corporate governance and firm valuation. Journal of Accounting and Public Policy, 25(4), 409-434.

Chauhan, Y., Lakshmi, K. R., \& Dey, D. K. (2016). Corporate governance practices, self-dealings, and firm performance: Evidence from India. Journal of Contemporary Accounting \& Economics, 12(3), 274- 289. 
Cheung, Y.-L., Connelly, J. T., Jiang, P., \& Limpaphayom, P. (2011). Does corporate governance predict future performance? Evidence from Hong Kong.Financial Management, 40(1), 159-197.

Diamond, D. W., \& Rajan, R. G. (2009). The credit crisis: Conjectures about causes and remedies. American Economic Review, 99(2), 606-610.

Erkens, D. H., Hung, M., \& Matos, P. (2012). Corporate governance in the 2007-2008 financial crisis: Evidence from financial institutions worldwide. Journal of Corporate Finance, 18(2), 389-411.

Fortin, R., Goldberg, G. M., \& Roth, G. (2010). Bank risk taking at the onset of the current banking crisis. Financial Review, 45(4), 891-913.

Gujarati, D. N. (2009). Basic econometrics. Tata McGraw-Hill Education.

Hassan, M. K., \& Bashir, A.-H. M. (2003). Determinants of Islamic banking profitability.In 10th ERF annual conference, Morocco (Vol. 7).

Hastuti, T. D. (2005). Hubungan Antara Good Corporate Governance dan Struktur Kepemilikan dengan Kinerja Keuangan (Studi Kasus pada Perusahaan yang listing di Bursa Efek Jakarta). Simposium Nasional Akuntansi VIII, 238-247.

Jensen, M. C., \& Meckling, W. H. (1976). Theory of the firm: Managerial behavior, agency costs and ownership structure. Journal of Financial Economics, 3(4), 305-360.

Kaihatu, T. S. (2006). Good corporate governance dan penerapannya di indonesia. Jurnal Manajemen Dan Kewirausahaan, 8(1), 1-9.

King, R. G., \& Levine, R. (1993). Financial intermediation and economic development. Capital Markets and Financial Intermediation, 156-189.

Klapper, L. F., \& Love, I. (2004). Corporate governance, investor protection, and performance in emerging markets.Journal of Corporate Finance, 10(5), 703-728.

Komite Nasional Kebijakan Governance. (2004). Pedoman Good Corporate Governance Perbankan Indonesia. Retrieved from http://www.knkg-indonesia.org/dokumen/Pedoman-GCGPerbankan.pdf

Levine, R. (1997). Financial development and economic growth: views and agenda. Journal of Economic Literature, 35(2), 688-726.

Mashayekhi, B., \& Bazaz, M. S. (2008). Corporate governance and firm performance in Iran.Journal of Contemporary Accounting \& Economics, 4(2), 156-172.

Mülbert, P. O. (2009). Corporate governance of banks.European Business Organization Law Review (EBOR), 10(3), 411-436.

OECD. (2015). G20/OECD Principles of Corporate Governance.OECD Publishing, Paris. Retrieved from http://dx.doi.org/10.1787/9789264236882-en

Otoritas Jasa Keuangan. (2014). Roadmap Tata Kelola Perusahaan Indonesia: Menuju Tata Kelola Emiten dan Perusahaan Publik yang Lebih Baik. Jakarta: OJK.

Owusu, A., \& Weir, C. (2016). The governance-performance relationship: evidence from Ghana. Journal of Applied Accounting Research, 17(3), 285-310.

Perry, P. (1992). Do banks gain or lose from inflation? Journal of Retail Banking, 14(2), 25-31.

Prasinta, D. (2012). Pengaruh good corporate governance terhadap kinerja keuangan.Accounting Analysis Journal, 1(2).

Rankin, M., Stanton, P., McGowan, S., Ferlauto, K., \& Tilling, M. (2012).Contemporary Issues in Accounting.John Wiley \& Sons Australia.

Satriadi, F., Bagaskara, M. A., Pranoto, T., \& Haryono, L. (2018). Pengaruh tata kelola perusahaan terhadap profitabilitas pada perusahaan yang terdaftar di Bursa Efek Indonesia. Studi Akuntansi \& Keuangan, Vol 1 (2), 186-209.

Seuraj, S., \& Watson, P. K. (2012). Banking Regulation: Does Compliance Pay in Emerging Economies? Evidence from Trinidad \& Tobago.Social and Economic Studies, 61, 131-144.

Shleifer, A., \& Vishny, R. W. (1997). A survey of corporate governance.The Journal of Finance, 52(2), $737-\quad 783$. 
Yasser, Q. R. (2011). Corporate governance and firm performance: an analysis of family and nonfamily controlled firms. The Pakistan Development Review, 47-62.

Zabri, S. M., Ahmad, K., \& Wah, K. K. (2016). Corporate Governance Practices and Firm Performance: Evidence from Top 100 Public Listed Companies in Malaysia. Procedia Economics and Finance, 35, 287-296.

Zagorchev, A., \& Gao, L. (2015). Corporate governance and performance of financial institutions. Journal of Economics and Business, 82, 17-41.

\section{Lampiran}

\section{Daftar Perusahaan Sampel}

\begin{tabular}{|l|l|l|l|}
\hline No & Nama Bank & ACGS & TARIF \\
\hline 1 & PT. BANK ARTA GRAHA INTERNASIONAL, Tbk & 62.360 & 64.706 \\
\hline 2 & PT. BANK CENTRAL ASIA, Tbk. & 73.452 & 74.670 \\
\hline 3 & PT. BANK CHINA CONSTRUCTION BANK INDONESIA, Tbk & 53.791 & 55.582 \\
\hline 4 & PT. BANK CIMB NIAGA, Tbk & 78.344 & 75.750 \\
\hline 5 & PT. BANK DANAMON INDONESIA, Tbk & 74.483 & 74.190 \\
\hline 6 & PT. BANK INTERNASIONAL INDONESIA, Tbk & 74.915 & 75.870 \\
\hline 7 & PT. Bank JTRUST INDONESIA, Tbk & 57.883 & 60.864 \\
\hline 8 & PT. BANK MANDIRI (PERSERO), Tbk & 72.517 & 74.310 \\
\hline 9 & PT. BANK MEGA, Tbk & 53.815 & 57.503 \\
\hline 10 & PT. BANK NEGARA INDONESIA (PERSERO),Tbk & 69.942 & 70.828 \\
\hline 11 & PT. BANK NUSANTARA PARAHYANGAN Tbk & 67.290 & 68.307 \\
\hline 12 & PT. BANK OCBC NISP, Tbk & 77.134 & 79.232 \\
\hline 13 & PT. BANK OF INDIA INDONESIA, Tbk & 48.742 & 49.820 \\
\hline 14 & PT. BANK PEMBANGUNAN DAERAH BANTEN, Tbk & 59.670 & 62.665 \\
\hline 15 & PT. BANK PERMATA, Tbk & 73.379 & 73.109 \\
\hline 16 & PT. BANK QNB INDONESIA, Tbk & 62.833 & 66.267 \\
\hline 17 & PT. BANK RAKYAT INDONESIA (PERSERO), Tbk & 78.083 & 77.191 \\
\hline 18 & PT. BANK RAKYAT INDONESIA AGRONIAGA, Tbk & 60.758 & 64.226 \\
\hline 19 & PT. BANK TABUNGAN PENSIUNAN NASIONAL Tbk & 79.143 & 77.671 \\
\hline 20 & PT. PAN INDONESIA BANK, Tbk & 76.250 & 76.471 \\
\hline 21 & PT. BANK BUKOPIN, Tbk & 64.302 & 66.267 \\
\hline 22 & PT. BPD JAWA BARAT DAN BANTEN, Tbk & 72.631 & 72.869 \\
\hline 23 & PT. BANK VICTORIA INTERNATIONAL, Tbk & 65.902 & 69.268 \\
\hline 24 & PT. BANK WOORI SAUDARA, Tbk & 54.114 & 56.182 \\
\hline 25 & PT. BANK TABUNGAN NEGARA (PERSERO), Tbk & 75.930 & 74.910 \\
\hline
\end{tabular}

